\title{
TTR
}

Traduction, terminologie, rédaction

\section{Juan Jesús Zaro, ed. Traductores y traducciones de literatura y ensayo (1835-1919). Granada, Comares, 2007, 410 p. and Diez estudios sobre la traducción en la España del siglo XIX. Granada, Atrio, 2008, 271 p.}

\section{Jorge Jiménez-Bellver}

Volume 27, numéro 1, 1er semestre 2014

URI : https://id.erudit.org/iderudit/1037128ar

DOI : https://doi.org/10.7202/1037128ar

Aller au sommaire du numéro

Éditeur(s)

Association canadienne de traductologie

ISSN

0835-8443 (imprimé)

1708-2188 (numérique)

Découvrir la revue

Citer ce compte rendu

Jiménez-Bellver, J. (2014). Compte rendu de [Juan Jesús Zaro, ed. Traductores y traducciones de literatura y ensayo (1835-1919). Granada, Comares, 2007, 410 p. and Diez estudios sobre la traducción en la España del siglo XIX. Granada, Atrio, 2008, 271 p.] TTR, 27(1), 244-249. https://doi.org/10.7202/1037128ar d'utilisation que vous pouvez consulter en ligne. 
principaux débouchés traditionnels y sont traités, mais également des profils professionnels plus récents, dont la communication technique et la localisation. Quant aux outils du traducteur, une distinction est établie entre ceux qui sont associés à la traduction automatique, à la traduction assistée par ordinateur, à la recherche terminologique et à l'exploitation de corpus. Sont également abordées les différences et les similitudes qui caractérisent l'université et le marché. Pour ce qui est de la responsabilité du traducteur, elle est traitée sous les angles de la responsabilité textuelle et interpersonnelle, et du point de vue du rôle actif $\mathrm{du}$ traducteur. Le chapitre se clôt sur une section portant sur la responsabilité et la protection juridique.

La traduction spécialisée: une approche professionnelle à l'enseignement de la traduction est un ouvrage riche, utile et bien structuré: le contenu annoncé est couvert de façon assez complète, des liens sont faits entre les différentes parties de l'ouvrage, et il y a un retour récapitulatif à la fin de chaque chapitre. En outre, les nombreux exemples fournis tout au long de l'ouvrage permettent de bien saisir la matière présentée et pourront assurément enrichir l'enseignement. Quant aux changements apportés par le traducteur pour les lecteurs canadiens, ils nous apparaissent heureux. La préface du traducteur contribuera sans nul doute à accroître la visibilité du traducteur spécialisé.

\section{Julie Arsenault Université De Moncton}

Juan Jesús Zaro, ed. Traductores y traducciones de literatura y ensayo (1835-1919). Granada, Comares, 2007, 410 p. and Diez estudios sobre la traducción en la España del siglo XIX. Granada, Atrio, 2008, 271 p.

Since 2007 the University of Málaga (Spain) website has hosted a digitized archive of translated texts into Spanish from the nineteenth and early twentieth centuries. ${ }^{1}$ This archive is the outcome of two research projects directed by Professor Juan Jesús Zaro, who also edited the two volumes reviewed here. The main criteria used in the selection of texts were linguistic and historical: the archive contains works translated from English, French, and

1. The archive can be accessed at: www.ttle.satd.uma.es. 
German that exerted a significant influence on both the source and target cultures (which explains why most of them are literary and scientific). English predominates as a source language in this regard, and William Shakespeare, Walter Scott, John Stuart Mill, and Charles Darwin stand out as the most influential authors. Along with translations, the archive contains historical, political, and cultural information related to their reception as well as translators' biographical information, constituting socalled "ediciones traductológicas", that is, editions based on and meant for translation research. The chapters in Traductores $y$ traducciones de literatura y ensayo (1835-1919) [Translators and Translations of Literary Works and Essays (1835-1919)] and Diez estudios sobre la traducción en la España del siglo XIX [Ten Research Studies on Translation in Nineteenth-century Spain] draw from the information contained in the editions, providing a complementary resource to the archive and a detailed introduction to the history of the texts included in it.

In addition to the 75-year period required for copyrighted works to enter the public domain, the nineteenth and early twentieth centuries were chosen because of the degree of social unrest and political struggle that characterized this period. As Juan Crespo argues in his contribution to the first volume (2007, p. 48), the nineteenth century in Spain was "un siglo en guerra" [a century of war], interspersed with only short intervals of peaceful relations. However, it was also the century when the middle class and women across Spain became literate, and libraries and newspapers made literary and scientific works more widely available. The result was a profusion of translations published to further diverse artistic, social, and political ends: translations of works that reproduced the values and ideologies of the Inquisition and the absolutist monarchy, translations published in London and Paris for Spanish liberal exiles and criollo liberals in Spain's former colonies in the Americas, translations commissioned during periods of constitutional rule that had previously been banned, translations for the new reading publics, and so forth.

Periods of "crises" and "turning points" (Even-Zohar, 1990) offer an invaluable source of data that can be used to analyze the role of translation in processes of both continuity and change in the receiving cultures. The chapters in the two volumes edited by Zaro show a marked interest in the study of translation norms 
(Toury, 2012) as a tool to uncover the policies and ideologies that governed the practice of translation in nineteenth- and early twentieth-century Spain. In what follows, I will focus on the two main findings of the project regarding norms. The first is that indirect translation from French was a preliminary norm (2008, p. 10). As pointed out above, most of the texts included in the archive were translated from French; however, most of their source texts were written in a language other than French (namely English). The second finding is that acceptability was the initial norm, judging from the abundant instances of "domestication" found in the translations (ibid.).

The heuristic potential of norm-based research to provide insights into the role of translations published under conditions of political instability and various forms of social control is beyond question. In this respect, the two works reviewed here attest to the significance of translation as a social and political activity and, more importantly, of translators as historically, culturally, and ideologically positioned actors. For example, in a chapter exploring politician and translator Eduardo Benot's ideas on translation, Crespo (2008, p. 66) combines politics and translation by way of the figure of "traductores políticos", that is, intellectuals who used translation to introduce progressive European ideas in Spain.

However, the use of the norms concept is open to criticism, particularly as regards the preliminary norm of translating indirectly from French. As Gideon Toury (2012, p. 82; my italics) points out, considerations concerning directness of translation involve "the threshold of tolerance for translating from languages other than the ultimate SLs." From this perspective, the goal of norm-based research is not so much to pinpoint norms per se (as conceptually different from conventions, idiosyncrasies, and so forth) as to map the thresholds of tolerance (or prohibition, preference, or obligation) around them. Regularities of behavior cannot be properly identified with a norm-or with any of the other categories of the so-called "normative scale" (Hermans, 1996), for that matter - unless some degree of normative force has been discerned (i.e., the norm's load and strength, which shape the range of behavior that is deemed tolerable); otherwise the explanatory power of the norms concept becomes severely limited, offering only partial insights into translational behavior. 
Normative force is notably absent from the discussion in the two volumes where it is argued that translating indirectly from French was a preliminary norm in nineteenth- and early twentieth-century Spain. Even though evidence that texts were indeed translated from French is provided (not only by comparing translated texts to both original texts and their French translations, but also by analyzing paratextual and epitextual elements), the argument is based strictly on quantitative data (i.e., most translations in the corpus are found to have been translated indirectly from French), whereas qualitative analysis of the data, which should illuminate the relationship between the quantitative findings and the possibility of indirect translation being a preliminary norm, is not part of the discussion.

An important consequence is that the argument not only becomes inconclusive but also makes the information provided in some of the chapters seem inconsistent. For example, Crespo (2007, p. 47) argues that the prevalence of "galicismo cultural" [cultural gallophilia] in Spain caused a lack of translators from modern languages other than French. On a similar note, Zaro (2007, p. 3; my italics) points out in the introduction to the first volume: “[A] las traducciones 'indirectas' o 'intermediadas', generalmente a través del francés, [...] obliga el general desconocimiento de lenguas extranjeras" ['Indirect' or 'intermediate' translation, generally by way of French, was inevitable because of a generalized lack of knowledge of foreign languages]. In these statements the following connection is made: gallophilia $\longrightarrow$ study of French to the detriment of other foreign languages $\longrightarrow$ need for indirect translation from languages other than French. Yet, the relation of this state of affairs with the argument that translating indirectly from French was a preliminary norm is far from clear.

Even though they confine and even preclude choice, norms are predicated upon choice. Norms exist because a choice can be made between at least two possible courses of action and, therefore, a decision has to be made. Where only a single course of action is possible, no choice can be made (other than refusing to take action, which does not strictly concern translational behavior). Therefore, a norm arising from a situation where choosing is not possible (as can be inferred from the use of "obliga" in the above quote) would contradict the very condition of possibility of norms 
(i.e., choice). How, then, could indirect translation from French be both a circumstantial obligation and a preliminary norm?

Again, quantitative research proves insufficient to give a satisfactory account of the relation of indirect translation with norms. In this regard, insights can be gained by considering direct translation phenomena and non-translational phenomena along with indirect translation phenomena. For example, even though plagiarism features in several of the contributions (most interestingly in the chapters by David Marín Hernández on Bazán's translation of Les Frères Zemganno and Carmen Acuña Partal on Bartrina's poem "Contra Darwin"), it is largely approached from a genetic perspective (that is, as an intertextual relation between a text and its source), to the detriment of a socio-cultural perspective (which could shed light on the norms of text production that were operative in the receiving culture). Also, the circulation in nineteenth-century Spain of a considerable number of original works written in French is mentioned (2007, p. 322) but not examined from the standpoint of the norms concept. Moreover, in neither volume are cases of pseudotranslation considered (despite the attention given to censorship), which could offer significant pointers to the receiving culture's expectations regarding translated texts. Research on these issues would provide the study of indirect translation with pertinent contextual information about the prestige of the mediating language/culture in the receiving culture, the thresholds of tolerance around original writing and translating, and the understanding of translation in the receiving culture.

A further criticism of the use of the norms concept involves the problematic causal relation between acceptability and domestication. As mentioned above, acceptability was found to constitute an initial norm in the translations under study (2008, p. 10). The assumption is that domesticating strategies follow naturally from acceptability (i.e., if acceptability is the norm, norm-abiding translators will surely resort to domesticating strategies). However, domestication does not necessarily ensue from acceptability - at least not the ethnocentric domestication denounced by Lawrence Venuti (1998).

According to Toury (2012, p.79), acceptability entails a "sweeping adherence to norms which originate and act in the target culture itself", norms which the researcher sets out to reconstruct. In this respect, the initial norm in a given culture at a 
given point in time could be just as well to foreignize (as Toury's proposed law of interference suggests). Just as shifts are considered translation universals (regardless of whether the initial norm tends toward adequacy or acceptability), adherence to target norms does not necessarily entail adherence to "domestic intelligibilities and interests" (Venuti, 1998, p. 11). In this case, the conflation of domestication and acceptability reflects an assumption (i.e., ethnocentric domestication ensues from acceptability) that, although certainly reasonable (ethnocentric domestication may indeed ensue from acceptability), compromises the explanatory power of the norms concept.

Notwithstanding the conceptual and methodological points raised, Traductores y traducciones de literatura y ensayo (1835-1919) and Diez estudios sobre la traducción en la España del siglo XIX make a significant contribution to translation historiography, providing insights into the involvement of translation in the formation of national identities, asymmetries of power and prestige, and intercultural relations, as well as translators' agency and visibility in nineteenth- and early twentieth-century Spain. The digitized archive and its related volumes should prove a valuable source for further research on these issues and serve as a model for future archives of translated texts.

\section{References}

Even-Zohar, Itamar (1990). "The Position of Translated Literature within the Literary Polysystem.” Poetics Today, 11, 1, pp. 45-51.

Hermans, Theo (1996). "Norms and the Determination of Translation: A Theoretical Framework.” In R. Álvarez and M. C. África Vidal, eds. Translation, Power, Subversion. Clevedon, Multilingual Matters, pp. 25-51.

Toury, Gideon (2012 [1985]). Descriptive Translation Studies - and beyond. Amsterdam/Philadelphia, John Benjamins.

Venuti, Lawrence (1998). The Scandals of Translation: Towards an Ethics of Difference. London and New York, Routledge.

JoRge JiMÉNEZ-BELLVER UNiversity OF TeXas AT BrownSVILle 